\title{
Editorial: Critical Approaches to Climate Change and Civic Action
}

\author{
Anabela Carvalho ${ }^{1 *}$, Chris Russill ${ }^{2}$ and Julie Doyle ${ }^{3}$ \\ ${ }^{1}$ Department of Communication Sciences, University of Minho, Braga, Portugal, ${ }^{2}$ School of Journalism and Communication, \\ Carleton University, Ottawa, ON, Canada, ${ }^{3}$ School of Art and Media, Centre for Spatial, Environmental and Cultural Politics, \\ University of Brighton, Brighton, United Kingdom
}

Keywords: critical research, civic action, climate change, power, cultural hegemony

\section{INTRODUCTION}

There is wide recognition that the dangers of climate change require urgent, large scale, and systemic changes (IPCC, 2018). There is also a growing awareness that these changes are not simply a question of carbon emissions and regulatory policies, but of democracy and societal transformation (e.g., Klein, 2014; Rasbash, 2019). In challenging the priority of the economic, regulatory, and technological solutions of an emissions paradigm, a diverse range of actors are centring questions of power, exclusion, and justice to recast climate change communication around the needs of societal transformation. The contemporary climate change movement is thus broader, more diverse, and more inventive than contemporary scholarship often suggests, reconfiguring climate action and climate communication as mutually interdependent.

The epistemological, conceptual and analytical challenges that result from taking the diversity of these actions seriously is worth critical attention and study. Responding to these challenges, the Research Topic on Critical Approaches to Climate Change and Civic Action focuses on the communicative dimensions of contemporary forms of climate action. By viewing the meanings of climate change as defined in communication practices, we center the role of communication in imagining, shaping, facilitating, contesting and enacting collective action on climate change. In doing so, we situate communication as constitutive of the epistemological, discursive and material conditions necessary for creating societal transformations at a systemic level. While the field of climate change communication has moved beyond its ad hoc origins and is now informed by a wide array of disciplines, including psychology, political science, and neuroscience, the constitutive aspect of communication is often minimized or elided in this work. A constitutive approach to communication, as Ballentyne (2016) reminds us, is distinguished by its attention to the coproduction of discourse (or communication practices) and reality, and by an understanding of climate change as both physically and socially produced. It also encourages critical approaches to communication that are more open, inclusive, and responsive to the emplaced and embodied knowledges that animate the climate change movement.

Our approach to this Research Topic has several features that follow from recognizing the constitutive element of communication. The articles engage in theoretical, empirical and critical reflection by situating communicative practices as constitutive of the relationships that make up our worlds. Articles in this collection are also critical in their attention to the questions of power and marginalization that invariably shape our understanding of climate change. "Critical," in this respect, does not mean sceptical or cynical toward climate science, but indicates an anti-essentialist engagement with the assumptions, norms, and inequalities in the systems of power that shape our collective futures. Questions of identity, meaning, interpretation, action, power, and human/ more-than-human relations are brought into the political foreground. Finally, the articles are inventive in allowing our concepts and epistemologies to be unsettled by events, and in resituating climate change communication with respect to wider visions and imaginaries of societal 
transformation. In this editorial piece, besides introducing the articles that are part of this Research Topic, we take the opportunity to discuss the nature and traits of critical communication research and how it can uniquely contribute to understanding civic action and societal transformation.

\section{WHY CRITICAL RESEARCH ON CLIMATE CHANGE COMMUNICATION AND CIVIC ACTION IS NEEDED}

A large part of the research on climate change produced within the social sciences has been strikingly $a$-social, i.e., focused on the individual rather than on social-level issues. Individual perceptions and actions-or what Shove (2010) termed the ABC model (Attitudes, Behaviour, and Choice)- have been at the core of most studies. People tend to be construed as consumers whose preferences, once modelled and typified, may be influenced through "nudging" or social marketing strategies (Carvalho and Peterson, 2012). Politics, in this approach, is often understood as associative of individuals and organized by a desire for consensus (Mouffe, 2018). Climate change communication is thus inscribed into neoliberal forms of government.

In communication-related areas, such research has frequently pointed at the potential for persuasion of the individual via appropriately "framed" messages. This is a top-down-or expert-to-lay-people-way of rationalizing and disciplining communicative practice. Type "communication" and "climate change" in a web search and you are very likely to find numerous references to "effective communication." The term "effectiveness" tends to be associated with an instrumental view of communication, whereby communication is conceived as a tool to a certain effect. In a linear fashion, words (or other codes of communication) tend to be viewed as vehicles for (pre-defined) meanings and successful communication as being about producing a specific relationship and outcome. In this perspective, climate change is seen as a problem that can be "solved" (Climate Xchange, 2021) and a "communication failure" is seen a large part of that problem. Such transmissional and mechanistic conceptions of communication overlook crucial aspects of meaning-making processes, such as socio-cultural contexts (and physical ones), relational dynamics, and powerrelated issues. This strand of research is often carried out within a (post-)positivist paradigm. It aims at identifying generalizable regularities in individuals' views or practices and works under the assumption that the aggregation of individual traits can lead to understanding what happens in societies.

The perspective adopted in this special Research Topic differs from those described above in multiple ways. Rather than an individual process, engagement with climate change is viewed as tied to social and material interactions, whereby meanings are shaped and challenged collectively. In addition, rather than positioning people as consumers (of products and ideas) and spectators (of politics), we are interested in anti-essentialist understandings of their agency as citizens in civic places. We posit that people's understandings of climate change, as well as of their positionality and potential agency in relation to climate change, are constituted in communication. Likewise, civic action is largely performed through communication practices.

Civic and political identities and subjectivities are discursively constituted (Foucault, 2002). ${ }^{1}$ Within this approach, citizenship is not seen as a formal status or reified category related to state and nationality; it is a condition of possibility for addressing collective matters politically via civic action. It is often in civic spaces that one's place in the political world comes to be perceived and performed. "Civic action can be defined as a form of citizenship practice consisting in mainly collective initiatives aimed at implementing rights, taking care of common goods or empowering citizens." (Moro, 2010, p. 145) Along these lines, we look at forms of civic involvement with- and intervention in debate and decision-making related to policies, institutional practices, and other processes relevant to societies-in this case, climate change-related matters.

Importantly, civic action is where struggles over the accepted forms of political change often take place, a space of agonism that mediates informal and institutional politics. Hajer et al. (2015) warned us to beware of "cockpit-ism," the assumption-often built into academic studies and political processes-that transition to sustainability can be managed top-down or from a policy standpoint. Critically, a number of scholars have highlighted the unruly and complex nature of social change (Shove and Walker, 2007; Smith and Stirling, 2010; Stirling, 2014; Escobar, 2020). The last few years have seen significant growth in initiatives led by civic groups with the aim of reconfiguring how climate change is addressed. In a context marked by lack of trust in politics and in spite of widespread practices of disinformation promoting suspicion (of others, of institutions, of journalism, etc), fear and individualism, a multiplicity of civic collective actions have been set off. ${ }^{2}$ These groups and their modes of intervention in public spaces have a significant potential for influencing how climate change is understood and how future societies are reimagined. Taken collectively, the challenge they pose to received ideas of political change and societal transformation is well worth the attention of climate change researchers.

Civic action on climate change has emerged in diverse locations, on a variety of scales, and has been led by different types of actors, from "legacy" non-governmental organizations, such as Greenpeace and Friends of the Earth, to internet-platform projects, such as 350.org or Avaaz, to place-based protectors of water and land, such as the Standing Rock resistance and the Inuit Petition on the "right to be cold." These groups use diverse means and tactics, including declarations of climate emergency, demonstrations, sit-ins, climate camps, pipeline protests, land

\footnotetext{
${ }^{1}$ There are also of course a myriad of material practices that influence people's subjectivity and political agency; but the meanings assigned to those depend on communication practices (Carpentier, 2017; Goodman et al., 2020). This approach hence calls for critical analyses of how everyday climate cultures and material practices are articulated through communication.

${ }^{2}$ Individual actions, movements and/or groups engaged in disinformation, deliberate distortion of scientific knowledge, gratuitous defamation and/or discrimination obviously cannot be seen as "civic."
} 
occupations, and social media. In the last few years, the youth movement for climate change has gained extraordinary prominence via school strikes and demonstrations and a strong online presence, especially after the constraints associated with the COVID-19 pandemic. Representing the diversity of civic action on climate change, the articles in this Research Topic include studies of civic action by Indigenous peoples and groups (Neubauer and Gunster; Tam et al.; CastroSotomayor), the Fridays for Future movement (Marquardt), spontaneous social movements (Kaijser and Lövbrand), coalitions between non-governmental organisations and various social groups (Fernandes-Jesus and Gomes; LoveNichols; Neubauer and Gunster; Bsumek et al.); and morethan-human forms of agency (Schutten and Shaffer).

The sections that follow discuss how an anti-essentialist and constitutive approach to critical research addresses key ideas in climate change communication, including action, consensus, meaning, story, place, power, and possibility.

\section{UNSETTLING CONSENSUS AND HEGEMONY IN CLIMATE CHANGE ACTION}

For a number of years, there has been a lot of talk around the world on the need for "action" on climate change. The term "action" often appears to be self-explanatory and consensual. Yet, its meanings can differ widely. As Hulme (2015, p. 900) notes:

\begin{abstract}
“The goals of 'action' on climate change might (...) be, inter alia, to limit global warming to two degrees, to deliver creation care, to design a planetary thermostat, to transform civilisation or to safeguard economic growth - or indeed to secure fair growth, zero growth or de-growth. All of these goals have prima facie credibility since they emerge from different readings of what climate change is about, inspired by different cosmologies and ethical or political values."
\end{abstract}

Specifically what action is being referred to, whom (and whose benefit) it is for, who it is led by, and what principles and assumptions underpin it are examples of key questions that ought to be posed; yet, most proposals for- and decisions in the name of-climate change "action" obscure those matters. Seemingly consensual framings result from processes of discursive naturalization and institutionalization and may have important consequences. Several scholars (e.g., Rothe, 2011; Swyngedouw, 2010, 2013) have spoken of a post-political condition in climate change. Policies are often made by economic and scientific technocrats rather than through a democratic decision-making process without alternatives or implications being made visible and confronted. Options and choices on a matter so vital to societies' futures appear confined to what is "thinkable" or "possible" within the free market technomanagerial approach that is dominant worldwide (Raso and Neubauer, 2016; Escobar, 2020). One of the goals of this Research Topic is to challenge the dominant political intelligibility on climate change and foreground other modes of agency and other forms of "climate action," thus showing that what appears natural and inevitable is not so. In contrast with linear models of communication and (post)positivist research, critical social scholarship does not just seek demonstrably "effective" formulas to influence people to reducing greenhouse gas emissions. Climate change and climate policies are considered not just as a matter of carbon maths (more or less carbon dioxide-equivalent concentration in the atmosphere) but more widely in terms of social distribution of risks/costs and benefits, in terms of justice and ethics (e.g., what impacts may a massive dam in the Amazon have for Indigenous communities that depend on the forest?), and via a deeper ecological thinking (e.g., to what extent may a monoculture plantation of trees sink carbon but decrease biodiversity?). 'The political', as explained below, is brought to the fore of social analysis.

The notions of "post-political" and "(de)politicization" have not always been well understood. In the US context, in particular, multiple voices have pointed to "politicization" of climate change as a problem. Pepermans and Maeseele (2016) offer a clear analysis of the different senses in which that word has been used; a brief contextualization and clarification of our understandings of those terms may be helpful here too. The concept of "post-political" draws on scholarship by Laclau (1996), Mouffe (2006), Rancière (2006) and others who have discussed the contingent (historically constructed) nature of existing forms of society and democracy. It is important to distinguish "politics," which refers to institutions and formal processes of political life, from "the political," which refers to a mode of representing democratic politics that recognises power and dissensus and opens up space to (radically) different ways of thinking society. In this context, "politicization" is linked to agonism, i.e., acceptance of the conflict and fractures that always occur in societies, and of the legitimacy (and indeed the desirability) of foregrounding them. In contrast, as Kenis (2018, p. 4) put it:

\footnotetext{
"a discourse can be said to be post-political when it (1) misrecognises the constructed and therefore contingent nature of the social, (2) conceals that each such construction entails certain exclusions and therefore generates conflicts or antagonisms, and (3) obfuscates that the construction of the social inevitably entails acts of power."
}

These issues are at the core of critical research. In a Gramscian fashion, it can be argued that suppressing (or making invisible) the socially constructed nature of institutions, of norms and indeed of most of the physical worlds that we inhabit aids dominant powers to be accepted (at least tacitly). The social and cultural processes whereby a social order is viewed as natural or inevitable are key to such cultural hegemony and ought to be at the core of social scholarship. Critical communication research unsettles hegemonies. It looks beyond dominant and seemingly unquestionable views to illuminate alternative possibilities.

Numerous civic groups have challenged technocratic, depoliticising, and neoliberal discourses to illustrate that there is no single option but multiple possibilities that are seeking wider articulation. Some groups reclaim structural changes in property 
and decision-making in energy systems, leading a wave of "energy democracy" that brings together community groups, environmental organizations, and workers unions (Energy Democracy, 2021). Others are connecting climate change to questions of human security to address forced migration and refugee crises (Climate and Migration Coalition, 2021; Climate Refugees, 2021). Still others emphasize prefigurative politics to provoke experimental forms of change, while Indigenous approaches to climate change often re-centre decolonial politics (Whyte, 2018; Escobar, 2019; Indigenous Climate Action, 2021; Indigenous Environmental Network, 2021). Although some civil society organizations pursue the dominant approach to ecological modernization, system-level alternatives have been developed, including degrowth, "buen vivir" (inspired in Indigenous movements from Central and South America), ecosocialism, ecofeminism, and climate justice. Why would we speak of "post-politics" despite these developments? Kenis (2018, p. 1) notes that "multiple voices on climate change do not equal politicisation." Indeed, if they are not acknowledged, made visible and recognised in their political status as "equals," those social agents and their proposals will "not exist" or "matter" symbolically and politically. Critical research can both expose the processes whereby they are obscured and contribute to their cultural and political recognition. That is a central goal for this Research Topic.

Critical research rests on ontological, epistemological and axiological principles that impact the ways in which social realities are conceived and studied (perspectives, types of data, methodologies, etc). Rather than separating a research object from the social and material contexts where it is situated, critical research often presumes a relational ontology that looks into interactions. In Fairclough's words, "critique" is "essentially making visible the interconnectedness of things" (1995: 36), a position that Escobar (2019) reminds us is characteristic of grassroots communities and knowledges informed by ecological struggles. This is different from research based on experiments and most survey studies, for instance, where it is assumed that individual behaviours or perceptions can be isolated from the particular and socially contingent sites where they emerge. Methodologically, critical social research often adopts interpretive approaches, involving listening to social subjects and understanding their viewpoints and experiences. Ethnomethodological approaches may be employed as they are sensitive to context and contingency. Rather than using tools such as a questionnaire with close-ended questions, which constrains answers and pre-conditions findings, critical research often looks at texts, images, or other materials that have been previously/naturally produced to emphasize the context-specific and conjunctural nature of meaning, story, place, as well as to bring reflexivity, power, and possibility to the fore.

Kaijser and Lövbrand's article in this Research Topic exemplifies an interpretive approach and inductive analysis. It focuses on stories written by a number of people who participated in an initiative titled Run for Your Life, which aimed to highlight citizens' views on climate change in anticipation of COP- 25 . Instead of using pre-formulated analytical categories that would "reduce"the data to given pre-defined topics or matters of concern, their inductive examination accounts for a rich diversity of meanings, as experienced/constructed by those that participated in this "climate performance":

"the collection of climate stories offers a powerful account of worry, sorrow, hope, connectivity, solidarity, and agency in face of climate change. They contain testimonies of changing weather patterns, loss of cultural traditions, protest against fossil fuel extraction, frustration with the lack of political action, and solidarity with the vulnerable across space, time, and species boundaries." (p. 8)

Power and identity are important aspects of critical research both in the outlook towards social realities and toward the researcher's own engagement with them. For instance, in this collection several articles draw on interview material and are careful to consider the implications of that kind of research relation. Tam et al. describe how Indigenous communities in the Arctic were interviewed in avoidance of researcher hegemony. They employed a thoroughly interpretive approach in their study of Inuit views on climate change that was sensitive to "community ownership of their own narrative and the way they are portrayed". (p. 3)

Critical researchers' reflexivity is well illustrated in the following excerpt from Castro-Sotomayor's article, which focuses upon the Indigenous organisation Gran Familia Awá Binacional (GFAB), located at the border between Ecuador and Colombia (p. 4):

"I tried to position myself primarily as "researcher" and "student" (...), and then as "Mestizo." However, giving emphasis to these identities was no guarantee for those identifications to be the salient ones in my interactions with Awá elites, neither they prevented Awá from ascribing me identities that exceeded my introductory avowed identities. Further, as part of an academic institution, to Awá people I was always-already an "external actor" associated to "economic interests of capitalist nature" FCAE, 2017, p. 25)."

Critical research on climate change and civic action may involve rethinking dominant research lenses in multiple ways. For example, whereas Castro-Sotomayor adopts a decolonial perspective, Kaijser and Lövbrand (p. 8) engage in a critique of the classical notion of ecological citizenship. "In contrast to the universal citizenship ideals traditionally invoked in green political theory," they argue, "the forms of agency articulated in [the] stories [written by participants in Run for Your Life] transcend the modern dualisms of mind/body, reason/emotion, men/ women, public/private, and culture/nature." A "corporeal approach" to citizenship allows them to recognize "the diverse forms of attachments that individuals have to social and material worlds" and how ecological agency is "grounded in the participants' every-day efforts to imagine and live with a changing climate." 
Love-Nichols makes a similar point in articulating an embodied understanding of political subjectivities to the coalitional politics of the climate change movement. In studying a politically conservative group in the United States, the Conservation Hawks, the regional and embodied engagements of hunter identities and their powerful political networks are foregrounded in a coalitional rather than polarizing form of climate activism.

"The nascent climate change movement builds from this context, using effective rhetorical strategies from other conservation movements by sportsmen and women. Climate change activists, for instance, draw on this collective identity to create new political subject positionings.”(p. 9).

A reinterpretation of the dominant ideology of anthropocentrism in the context of zoos as conservation sites is undertaken by Schutten and Shaffer, who argue for an imaginative rearticulation of captive zoo animals as agents of change. Utilising auto-ethnographic techniques of embodied listening, the authors place critical attention on the corporeal responses of listening to captive animals-through visits to an animal park in the United States-and "our" complicity in their captivity. They argue that captive animals should be recognised as a "rhetorical community," comprising the institution of the zoo, "other-than-human animals, visitors, staff, the exhibits, and the interactions that happen between and within these elements" (p. 2). Focusing upon captive animals as a rhetorical community, "shifts critical rhetoric by deconstructing an anthroponormative (Seegert, 2014) discourse that prioritizes human meaningmaking. Creaturely rhetoric accounts for the communicative/ rhetorical acts of more-than-humans, which may function beyond human sensemaking." (p. 2).

Creaturely rhetoric disrupts human/more-than-human hierarchies to firmly place the ecological consequences of human activities onto humans. Problematising human behaviour through embodied listening to more-than-humans also repositions animals as civic agents who have been displaced and relocated. Schutten and Shaffer argue that understanding animals as civic agents-stakeholders within climate action-requires us to take responsibility for animal displacement as a consequence of human induced climate change and to foreground more-than-human perspectives.

Enhancing attention to story and place in its geographical and cultural dimensions is one important way of considering contextual factors in critical research on climate change. Indeed, whilst talk on climate change has been widely associated with the "global" (scale, space, system...), Escobar (2019: $\mathrm{n} / \mathrm{p}$ ) has challenged globalist theories of social change and societal transformation to advocate for "a different way of understanding the relation between place, locality, and direct democracy." Instead of 'downscaling' global knowledge, Escobar revisits the way localism and globalism are often articulated to suggest that "' $\mathrm{r}$ ] adiating out' horizontalism, rather than scalingup, may organize a new view of social change," and affirms the anti-essentialist insight that our ideas of place, locality, and region are not pregiven or self-evident, but "an emergent result of enactments of new politics of the real and the possible." Although in different ways, contributors in this Research Topic bring specific places to the fore in their analyses of climate civic action, including border regions between Ecuador and Colombia (Castro-Sotomayor), western Canada and Canada's Nunavut Territory (Neubauer and Gunster; Tam et al.), Northern Europe (Kaijser and Lövbrand), rural western US (Love-Nichols), Algarve, Portugal (Fernandes-Jesus and Gomes), and a US zoo (Schutten and Shaffer).

\section{UNDERSTANDING CONSTRAINT AND POSSIBILITY IN CLIMATE CHANGE COMMUNICATION}

Fuchs (2010) maintains that critical communications studies are about "how communication is embedded into relations of domination," as well as about "finding alternative conditions of society and communication that are non-dominative" and with "the struggles for establishing such alternatives." (n/p) (cf. Craig, 1999). An explicit commitment to the analysis of power and its social functioning is indeed a distinct characteristic of critical communication research. Multiple research traditions underpin this, including the Frankfurt School, Foucauldian social theory, post-development and (post-)Marxist thought. The common element running through those types of analysis is a concern with how the (re)production of inequality is tied to certain communication practices. Power-in its multiple facets-is intricately connected with the generation of anthropogenic climate change, as well as with neoliberal policies to address it. It is no surprise then that questions of power cut across all the contributions to this collection. At the same time, Escobar's (2020, p. xii) call to open ourselves to "how the active critical stance by movement activists summons us, personally and collectively, into a politics and ethics of interdependence and care" is present in several of these articles.

Tam et al. argue in their article that "the dominant scientific and civic view of climate change, its effects, its solutions, and its victims are influenced strongly by a Western or Global North sensibility, and the perspectives of distant others such as Indigenous, poor, developing or Global South communities are under-represented." (p. 4). Kyle Whyte (2017, 2018) has also illustrated the persistence of such colonial thinking in our ideas of climate change and politics. Engaging with Inuit people's understandings of climate change, Tam et al. discuss how meanings that become dominant around the world about a particular space often do not originate in the discourse of the peoples that inhabit it, and that best know and understand it, but elsewhere; their article illustrates the need to accept the epistemologies and ontologies of peoples that have long inhabited places and to support actions toward Indigenous resurgence.

Several works in this Research Topic turn the research spotlight to some of the least visible social groups and communities. That is, per se, a key aspect of academic positioning in the politics of climate change communication. 
Castro-Sotomayor looks at Gran Familia Awá Binacional, a transboundary Indigenous organization, and linguistic alienation from debates on climate change. He defines "at-themargin organizations," like this one, "as those that (1) are not located in urban spaces; (2) have limited access to technology; and, (3) use non-dominant languages as a central element of their collective identity and struggle" (p. 2) Indigenous views are important to the article by Neubauer and Gunster, who focus on how First Nations-in alliance with various NGOs-fought a projected gas pipeline in Western Canada.

The article by Fernandes-Jesus and Gomes looks at the struggles of regional and national grassroot movements in Portugal in alliance with environmental NGOs against fossil fuel extraction projects. Through in-depth interviews with highly engaged activists, they found that political agency was gained through intentional strategies and communication tactics that connected with institutional power, legal procedures and popular mobilisation. Building bridges with multiple players enabled collective movement building. Such "power to act', the authors suggest, should be a key communication strategy for collective movement building and climate action.

Bsumek et al. examine the discourse of Bill McKibben, a famous U.S. strategist for climate change politics, whose work straddles the intersections of populist appeal, strategic action, and policy efficacy. In their analysis, Bsumek et al. use McKibben's speeches to reflect critically on the conception of strategy and power that inhere in US centered discourses of climate change communication to develop a conception of "strategic gesture" that troubles the usual dichotomies in strategic communication (symbolic/material; public/policy; strategic/impossible). In this respect, ideas of strategic climate change communication are resituated and assessed with respect to more imaginative and complex notions of social transformation strategy.

Marquardt examines student mobilizations and discourses. Whereas so much is at stake for them, young people are often delegitimated as voices in debates and decisions on climate change. Perhaps the most radical-and just-viewpoint, in this sense, is the one that puts more-than-human species at the center of the analysis, as Schutten and Shaffer's article does. Similarly, Castro-Sotomayor's article points to the more-than-human worlds that are suppressed in dominant discourses on climate change.

There is no question that civic action is structurally constrained by exclusionary discourses and that their analysis is a pressing concern, especially given the white supremacist and extreme right forms of populist politics. Bsumek et al., Marquardt, and Neubauer and Gunster, all point to a constrained populism that is emergent in a variety of sites, including Bill McKibben's speeches, the youth movement's reliance on technocratic conceptions of science, and the "ecological populist" story of pipeline politics in North America. These analyses recognize that communication practices often produce the conditions, possibilities, and obstacles to social change, while hinting at an alternative form of populist appeal. Meanings are constantly produced in communication practices, and thereby given (shared) understandings of reality that are either reproduced or challenged and possibly modified. Neubauer and Gunster clearly illustrate the flux of meaning when they show how opponents of a projected pipeline in Canada's West Coast turned around the idea of foreign connections and support that others tried to associate with them, and ultimately were successful in halting that project.

Besides representations of the (desired) world, the production of social relations and identities is also dependent on communication practices. In Neubauer and Gunster's case, political frontiers internal and external to the anti-pipeline movement were constructed and reconstructed as time went by, opening up spaces for transformative collaboration. A similar sense of possibility is afforded by Marquardt's engagement with the youth movement for climate change. $\mathrm{He}$ discusses some of the difficulties and tensions that develop when 'science driven' arguments are used to situate demands for societal transformation. While elevating youth voices to challenge assumptions about who should determine the future of climate change action, the school strikes amplified the tension between reconciling desires to prioritize science, technology, and political neutrality and the political challenges that are necessary for wider social change.

Communication practices can perturb meanings that appear fixed. As Kaijser and Lövbrand note in their piece, art activism, for instance, can "perform counter-politics by disrupting dominant narratives, de-normalizing attachments to fossil fuels and advancing an enlarged and transformed sense of self and the world" (p. 8). A constitutive reading of communication means that language/discursive practice is the producer of both (symbolic) constraint and the realm of possibility. Critical research is, in Foucauldian terms, about the problematization of thought. It may involve opening up the "black box" of predetermined political options, looking beyond the manifest and beyond the existing, even beyond the imagined, and inquire into possibilities that were previously unseen.

\section{CONCLUSION}

In this Research Topic, we forward a critical approach to climate change that makes the concepts and categories of thinking more responsive to the diverse demands for societal transformation that are shaping our collective futures. We draw inspiration from Hausendorf and Bora (2006) to see citizenship as realized in communication and amenable to research on communication: "Focussing on citizen participation as communication, we propose a concept that allows for and simultaneously requires an empirical reconstruction of citizenship conceptualized as a communicative achievement." ( $p$, 23; our emphasis). In encouraging a constitutive approach, our concepts and methods are understood not as reflections or mirrors of reality with special access to the truth, but as engaged with projects of societal transformation, a potential often foreclosed by reified notions of power, politics, and policy.

In reflecting critically on our conceptions of climate change communication, we seek to enlarge the range of knowledge, experiences, and embodied places that should matter in our work. Joosse et al. (2020, p. 768) have rightly pointed that it is 
crucial to discuss "from what position we are critical (of what and what is our role?), engaged (for and with whom?) and change oriented (what and whose imagined futures do we aim to support?)". As many before us have pointed out, research is always value-laden. Nonetheless, values can be grounded by empirically sustained and comprehensive analyses of social change and what (may) result(s) from it. Our defense of politicising discourses-and politicising discursive research-builds upon decades of empirical research on climate change communication that has shown the symbolic reinforcement of techno-managerial neoliberal discourses in media (e.g., Menzo and Padfield, 2016) and other public spaces, confining climate change action to the parameters of the capitalist project of the Green Economy, which has been clearly inadequate to respond to the challenges faced by current societies (Newell and Peterson, 2010; Methmann et al., 2013; Kenis and Lievens, 2015; Escobar, 2020). The "politics of transformations" (Meadowcroft, 2009) that are needed to address climate change necessarily implicates particular worldviews and ideological stances, as well as differential power resources of various social actors. Such transformations are likely to have re-distributional consequences (Patterson et al., 2017). Arguably, then, the social sustainability (Whitton et al., 2016) of those changes requires open debates, plural access and inclusive participation with respect for equity, fairness and justice (in its multiple dimensions) aided by a critical awareness of the historical exclusions and neoliberal erosions that shape the places where values are enacted.

Critical communication research has been key to making visible how oppression, discrimination and domination are

\section{REFERENCES}

Ballantyne, A. G. (2016). Climate Change Communication: what Can We Learn from Communication Theory? Wires Clim. Change. 7 (3), 329-344. doi:10.1002/wcc.392

Carpentier, N. (2017). The Discursive-Material Knot: Cyprus in Conflict and Community media Participation. Peter Lang Publishing Group. New York, doi:10.3726/978-1-4331-3754-9

Carvalho, A., and Peterson, T. R. (2012). "Reinventing the Political: How Climate Change Communication Can Breathe New Life into Contemporary Democracies (Pp. 1-28)," in A. Carvalho and T. R. Peterson. Editors Climate Change Politics: Communication and Public Engagement. (Amherst, NY: Cambria Press).

Climate and Migration Coalition (2021). Home page. https://climatemigration.org. uk. Accessed March 20, 2021.

Climate Refugees (2021). Home page https://www.climate-refugees.org/our-team. Accessed March 20, 2021.

ClimateXChange (2021). Communicating the Climate Crisis. Available at: https:// climate-xchange.org/communicating-the-climate-crisis/. Accessed February 7, 2021.

Craig, R. T. (1999). Communication Theory as a Field. Commun. Theor. 9 (2), 199-161. doi:10.1111/j.1468-2885.1999.tb00355.x

Energy Democracy (2021). Home page. Durham, https://energy-democracy.net Accessed February 7, 2021.

Escobar, A. (2019). The Global Doesn't Exist, a Contribution to GTI Forum Think Globally, Act Locally? Great Transition Initiative. available at: https:// greattransition.org/gti-forum/global-local-escobar Accessed March 15, 2021.

Escobar, A. (2020). Pluriversal Politics: The Real and the Possible. Duke University Press. doi:10.1515/9781478012108

FCAE (2017). Plan de Vida de la Nacionalidad Awá 2017-2023. Ibarra: Federación de Centros Awá del Ecuador. inextricably intertwined with uses of language (verbal, visual and/or others). Articles in this collection take those kinds of constraints either as the core or the backdrop of their analyses of civic action on climate change. Some (Castro-Sotomayor, Tam et al.) explicitly show how prevailing views and policies on climate change have largely excluded numerous discourses and voices from debates. Many also show how social groups struggling against dominant views use language to contest the claims of those in power and to promote alternative views and alternative visions of sustainable futures (Fernandes-Jesus and Gomes; Neubauer and Gunster; Schutten and Shaffer). New discourses (even if simple "gestures") can counter the "sense of inevitability" (Bsumek et al., p. 7) that often blinds us to radically different possibilities.

Our reflexive and (self-)critical approach sharpens the responsibility of acknowledging limitations and exclusions in our own work. The articles in this Research Topic offer important contributions but do not yet represent a wide enough engagement with the problems, cultures and places that are relevant to the field, including the important work found in Black studies and Indigenous resurgence movements. Hopefully, there is more to come.

\section{AUTHOR CONTRIBUTIONS}

AC wrote extensive parts of the editorial. CR wrote multiple paragraphs and made extensive revisions to the initial drafts. JD added more writing and revised the text.

Fairclough, N. (1995). Critical Discourse Analysis: The Critical Study of Language. London; New York: Longman.

Foucault, M. (2002). The Archaeology of Knowledge. (A.M. Sheridan Smith, Trans.): Abingdon: Routledge.

Fuchs, C. (2010). Critical Theory of Information, Communication, Media and Technology. Glossarium BITri. Available at: http://glossarium.bitrum.unileon. es/Home/teoria-critica-de-la-informacion/critical-theory-of-information?tmpl= \%2Fsystem\%2Fapp\%2Ftemplates\%2Fprint\%2F\&showPrintDialog=1. Accessed February 9, 2021.

Goodman, M. K., Doyle, J., and Farrell, N. (2020). Practising Everyday Climate Cultures: Understanding the Cultural Politics of Climate Change. Climatic Change. 163, 1-7. doi:10.1007/s10584-020-02863-7

Hajer, M., Nilsson, M., Raworth, K., Bakker, P., Berkhout, F., De Boer, Y., et al. (2015). Beyond Cockpit-Ism: Four Insights to Enhance the Transformative Potential of the Sustainable Development Goals. Sustainability. 7 (2), 1651-1660. doi:10.3390/su7021651

Hausendorf, H., and Bora, A. (2006). "Communicating Citizenship and Social Positioning: Theoretical Concepts," in H. Hausendorf and A. Bora. Editors Analysing Citizenship Talk. Social Positioning in Political and Legal DecisionMaking Processes. (Amsterdam: John Benjamins), 23-49.

Hulme, M. (2015). (Still) Disagreeing about Climate Change: Which Way Forward? Zygon. 50 (4), 893-905. doi:10.1111/zygo.12212

Indigenous Climate Action (2021). Available at: https://www.indigenous climateaction.com. Accessed March 20, 2021.

Indigenous Environmental Network (2021). Available at: https://www.ienearth. org/. Accessed March 20, 2021.

IPCC (Intergovernmental Panel on Climate Change) (2018). Global Warming of $1.5^{\circ} \mathrm{C}$. An IPCC Special Report on the Impacts of Global Warming of $1.5^{\circ} \mathrm{C}$ above Pre-industrial Levels and Related Global Greenhouse Gas Emission Pathways, in the Context of Strengthening the Global Response to the Threat of Climate Change, Sustainable Development, and Efforts to Eradicate Poverty. Geneva, 
Switzerland: World Meteorological Organization. Available at https://www. ipcc.ch/sr15/. Accessed February 8, 2021.

Joosse, S., Powell, S., Bergeå, H., Böhm, S., Calderón, C., Caselunghe, E., et al. (2020). Critical, Engaged and Change-Oriented Scholarship in Environmental Communication. Six Methodological Dilemmas to Think with. Environ. Commun. 14 (6), 758-771. doi:10.1080/17524032.2020.1725588

Kenis, A., and Lievens, M. (2015). The Limits of the Green Economy. London: Routledge. doi:10.4324/9781315769707

Klein, N. (2014). This Changes Everything: Capitalism vs. The Climate. New York: Simon \& Schuster

Kenis, A. (2018). Post-politics Contested: Why Multiple Voices on Climate Change Do Not Equal Politicisation. Environ. Plann. C: Polit. Space 37, 831-848. doi:10.1177/0263774x18807209

Laclau, E. (1996). Emancipation(s). London: Verso.

Manzo, K., and Padfield, R. (2016). Palm Oil Not Polar Bears: Climate Change and Development in Malaysian media. Trans. Inst. Br. Geogr. 41, 460-476. doi:10.1111/tran.12129

Meadowcroft, J. (2009). What about the Politics? Sustainable Development, Transition Management, and Long Term Energy Transitions. Pol. Sci. 42 (4), 323-340. doi:10.1007/s11077-009-9097-z

Methmann, C., Rothe, D., and Stephan, B. (2013). Deconstructing the Greenhouse. Interpretive Approaches to Global Climate Governance. (London and New York: Routledge).

Moro, G. (2010). "Civic Action," in H. K. Anheier and S. Toepler. Editors International Encyclopedia of Civil Society. (New York: Springer). doi:10.1007/978-0-387-93996-4_128

Mouffe, C. (2006). On the Political. London: Routledge.

Mouffe, C. (2018). For a Left Populism. New York: Verso.

Newell, P., and Paterson, M. (2010). Climate Capitalism: Global Warming and the Transformation of the Global Economy. Cambridge University Press.

Patterson, J., Schulz, K., Vervoort, J., Van Der Hel, S., Widerberg, O., Adler, C., and Barau, A. (2017). Exploring the Governance and Politics of Transformations towards Sustainability. Environ. Innovation Societal Transitions. 24, 1-16. doi:10.1016/j.eist.2016.09.001

Pepermans, Y., and Maeseele, P. (2016). The Politicization of Climate Change: Problem or Solution? Wiley Interdiscip. Rev. Clim. Change. 7 (4), 478-485. doi: $10.1002 /$ wcc. 405

Rancière, , J. (2006). Hatred Of Democracy. London: Verso.

Rasbash, Z. (2019). Climate Striker: We Must Take on Capitalism if We Want to Avert Chaos. Red Pepper, 14 March 2020. Available at: https://www.redpepper. org.uk/climate-striker-we-must-take-on-capitalism-if-we-want-to-avert-chaos/ (Accessed March 19, 2021).
Raso, K., and Neubauer, R. J. (2016). Managing Dissent: Energy Pipelines and "New Right" Politics in Canada. Can. J. Commun. 41 (1), 115. doi:10.22230/ cjc.2016v41n1a2777

Rothe, D. (2011). Managing Climate Risks or Risking a Managerial Climate: State, Security and Governance in the International Climate Regime. Int. Relations 25 (3), 330-345. doi:10.1177/0047117811415486

Shove, E. (2010). Beyond the ABC: Climate Change Policy and Theories of Social Change. Environ. Plann. A 42, 1273-1285. doi:10.1068/a42282

Shove, E., and Walker, G. (2007). Caution! Transitions Ahead: Politics, Practice and Sustainable Transition Management. Environ. Plann. 39 (4), 763-770.

Smith, A., and Stirling, A. (2010). The Politics of Social-Ecological Resilience and Sustainable Socio-Technical Transitions. Ecol. Soc. 15 (1), 11, 2010 . [online] URL: http://www.ecologyandsociety.org/vol15/iss1/art11/. Accessed February 5, 2021.

Stirling, A. (2014). Emancipating Transformations: From Controlling 'The Transition' to Culturing Plural Radical Progress, STEPS Working Paper 64. Brighton: STEPS Centre.

Swyngedouw, E. (2010). Apocalypse Forever? Theory. Cult. Soc. 27 (2-3), 213232. doi:10.1177/0263276409358728

Swyngedouw, E. (2013). The Non-political Politics of Climate Change. ACME: Int. E-Journal Crit. Geographies 12 (1), 1-8. Available at: https://acme-journal.org/ index.php/acme/article/view/948.

Whitton, J., Parry, I. M., Akiyoshi, M., and Lawless, W. (2016). Conceptualizing a Social Sustainability Framework for Energy Infrastructure Decisions. Energ. Res. Soc. Sci. 8, 127-138. doi:10.1016/j.erss.2015.05.010

Whyte, K. (2017). Indigenous Climate Change Studies: Indigenizing Futures, Decolonizing the Anthropocene. English Lang. Notes 55, 153-162. doi:10.1215/00138282-55.1-2.153

Whyte, K. (2018). Indigenous Science (Fiction) for the Anthropocene: Ancestral Dystopias and Fantasies of Climate Change Crises. Environ. Plann. E: Nat. Space 1, 224-242. doi:10.1177/2514848618777621

Conflict of Interest: The authors declare that the research was conducted in the absence of any commercial or financial relationships that could be construed as a potential conflict of interest.

Copyright (C) 2021 Carvalho, Russill and Doyle. This is an open-access article distributed under the terms of the Creative Commons Attribution License (CC $B Y)$. The use, distribution or reproduction in other forums is permitted, provided the original author(s) and the copyright owner(s) are credited and that the original publication in this journal is cited, in accordance with accepted academic practice. No use, distribution or reproduction is permitted which does not comply with these terms. 